\title{
Religiosity differences in the transition to first intercourse before age 18 among Polish students
}

\author{
Wiktoria Wróblewska@i
}

\author{
Correspondence: wwrobl@sgh.waw. \\ pl \\ Institute of Statistics and \\ Demography, SGH Warsaw School \\ of Economics, al. Niepodległości \\ $162,02-554$ Warsaw, Poland
}

\begin{abstract}
Poland is a Catholic country and is one of a few countries in Europe where the percentage of people declaring themselves as non-believing remains rather low. Thus, most young Poles are brought up in Catholic families and receive religious instruction at school.

The purpose of this study is to estimate the effects of religiosity and gender on the risk of first intercourse before age 18 among university students in Poland. We analysed data from two comparative studies of affective life, sexual behaviour, and attitudes conducted among university students in 2001 and 2013. We used survival analysis techniques to test for relative differences in the effects of religiosity on the timing of first sexual intercourse. While the results confirm that religiosity was a significant differentiating factor in the sexual behaviours of students in Poland, they also show that religiosity was a significant predictor of sexual abstinence only if a young person regarded religion as very important. The unadjusted median age at first sex for the participants who attached no or little importance to religion was more than 2 years lower than the median age among those who considered religion very important and attended church services regularly. The findings also indicate that there were significant gender differences, with young males transitioning to sex earlier than young females, albeit only among the 2001 cohort. The multivariate analyses confirm the absence of significant gender differences in FSI before age 18 within religious groups (controlling for other factors) in the cohort of students born after 1990. The results for control variables are consistent with the literature indicating that growing up in a two-parent household has a protective effect, and that teenage lifestyles are significant. Our observation of a distinct polarity of students with respect to religiosity and the timing of sexual debut may be a starting point for further analyses of FSI determinants.
\end{abstract}

Keywords: Religiosity, Transition to first sexual intercourse, Gender differences, Students, Poland (c) The Author(s). 2020 Open Access This article is licensed under a Creative Commons Attribution 4.0 International License, which permits use, sharing, adaptation, distribution and reproduction in any medium or format, as long as you give appropriate credit to the original author(s) and the source, provide a link to the Creative Commons licence, and indicate if changes were made. The images or other third party material in this article are included in the article's Creative Commons licence, unless indicated otherwise in a credit line to the material. If material is not included in the article's Creative Commons licence and your intended use is not permitted by statutory regulation or exceeds the permitted use, you will need to obtain permission directly from the copyright holder. To view a copy of this licence, visit http://creativecommons.org/licenses/by/4.0/. 


\section{Introduction}

The erosion of the traditionally close association between sex and marriage and the growing gap between the age at sexual initiation and the age at marriage are elements of the extensive changes in values related to family life and household formation that have been taking place since the end of the 1960s in Northern and Western European countries, Mediterranean countries, and Canada and the USA (Lesthaeghe, 2010; Surkyn \& Lesthaeghe, 2004; Lesthaeghe \& Neidert, 2006). These changes have been accompanied by a lowering of the age at sexual initiation in consecutive generations of teenagers and young adults, and particularly of women (e.g. Bajos, Guillaume, \& Kontula, 2003; AGI, 1994; Wellings et al., 2001).

In Eastern and Central European (ECE) countries, the diffusion of these new partnership and family formation patterns became possible in the 1990s after the collapse of the state socialist regimes. In particular, the ECE countries have been undergoing a process of marriage and childbearing postponement that has led to sharp declines in the TFR to levels below 1.3 (the "lowest-low fertility" phenomenon), increases in the number of extramarital births, growing acceptance of unconventional living arrangements, and the spread of the new behaviour among the younger cohorts (Lesthaeghe \& Surkyn, 2002; Sobotka, 2008; Pongracz \& Speder, 2008; Kowalska \& Wróblewska, 2008; Hoem, Kostova, Jasilioniene, \& Muresan, 2009). In the ECE countries, the social transformation and sexual revolution that occurred in Western Europe were delayed, in part due to the lack of information and technology while these countries were behind the Iron Curtain, which limited access to modern contraception (Bajos et al., 2003; Bajos et al., 2010; Sobotka, 2008).

In addition to these structural and technological processes, among the important factors that have supported the spread of new attitudes and behaviours are cultural changes and secular trends, which are elements of broader social changes in the modern period (Giddens, 2001; Liefbroer, 1999; Billari, Caltabiano, \& Dalla Zuanna, 2007; Pickel, 2011). In most ECE countries, forced secularisation policies implemented during the communist era considerably weakened the position of the Church, causing institutional religiosity to decline sharply (Molteni, 2017; Müller \& Neundord, 2012; Borowik, 2006). After the collapse of communism, there was a revival in religious practices and religious belief that was particularly noticeable in the younger cohorts in Orthodox countries, who were socialised after the regimes had ended (Tomka, 1995; Gautiert, 1997; Borowik, 2002; Müller \& Neundord, 2012; Brenner, 2016). In Catholic Eastern European countries, religious practices have decreased steadily while religious belief has increased slightly or remained stable. Thus, there is every reason to believe that these countries are preparing to undergo the same process of secularisation as Western European countries (Pickel, 2009; Pollack, 2008; Northmore-Ball \& Evans, 2016). In more secular regions, where religion has less influence over various spheres of social life and the culture is more liberal, these behavioural patterns have spread more rapidly than they have in countries where religion and traditional family values play a larger role (Lesthaeghe \& Surkyn, 2002; Sobotka, 2008; Lesthaeghe \& Neidert, 2006; Hoem et al., 2009; Lesthaeghe, 2010). There is a considerable body of research showing that there is a positive association between religion and more conservative sex-related attitudes and behaviour at different stages in the life course (e.g. Frejka \& Westoff, 2008; Vignoli \& Salvini, 2014; Thornton \& Camburn, 1987; Eggebeen \& Dew, 2009; Frątczak \& Sikorska, 2009; Burdette, Hill, \& Myers, 2015). 
Our analysis focuses on the relationship between religiosity and the sexual debut of adolescents. Several empirical studies that were initiated as early as the 1970s have documented that religiosity lowers the risk of initiation of sexual intercourse among adolescents. A review of 10 longitudinal studies on adolescent sexual behaviour in the USA published between 1975 and 2001 found evidence that having a stronger religious affiliation, attending church regularly, or self-reports of the importance of religion were associated with a delayed initiation of sexual intercourse (Rostosky, Wilcox, Wright, \& Randall, 2004). This association was found to be more consistent for females than for males. Similar findings have been reported for teenage and young adult Americans in the last 15 years by Rostosky, Regnerus, and Wright (2003); Lefkowitz, Gillen, Shearer, and Boon (2004); Regnerus (2007), Burdette and Hill (2009); Eggebeen and Dew (2009); Haglund and Fehring (2009); and Landor and Simons (2019); and for teenagers in European countries by Rizzi (2004); Coleman and Testa (2008); Caltabiano, Dalla Zuanna, and Rosina (2006); Štulhofer, Šoh, Jelaska, Baćak, and Landripet (2010); Pedersen (2014); and Stranges and Vignoli (2019). All of these studies have found that religiosity plays a significant role in delaying sexual initiation among adolescents in both Catholic countries such as Italy and Croatia, and Protestant (and also more secular) societies such as Norway. For example, a study conducted among Croatian students demonstrated that religiosity was associated with a lower likelihood of sexual debut among females (Štulhofer et al., 2010). The results of two comparable studies (SELFY 2001 and 2017) of large samples of Italian university students confirmed that religion had a strong influence on sexuality and, in particular, that religiosity played a role in whether students maintained their virginity status (Stranges \& Vignoli, 2019). A longitudinal study among young Norwegians found that membership in a Christian denomination and frequent church attendance in adolescence (measured at the age of 16) were associated with delayed sexual intercourse and having had a smaller number of sex partners at ages 21 and 28 (Pedersen, 2014).

However, little is known about sexual initiation and religion among adolescents in Poland and particularly during the social transformation that occurred in the country following the systemic transition that began in 1989. The failure to include information about religion and religious practices in studies of attitudes and sexual behaviour in Poland may have been due to the nearly universal membership in the Catholic Church and the confessional homogeneity in the country. The first study for Poland that addressed these issues, which is also analysed in this paper, was conducted in 2001 among university students. However, the findings of this study have not received much attention to date (Caltabiano, Dalla Zuanna, \& Rosina, 2007; Wróblewska, Strzelecki, \& Matysiak, 2003).

The main objective of this study is to examine the association between religiosity and the risk of first intercourse before age 18 among university students in Poland. The analysis focuses on changes in religiosity and in the gender patterns of first sexual intercourse (FSI).

To achieve our aim, we pose the following two core research questions: (1) Are there differences in religiosity and entry into adult sexuality between young Poles who were born before the systemic changes of the 1990s and those who were born a decade later? (2) Does the influence of religion on FSI differ between females and males? We also seek to answer the following questions: (3) Does the religiosity of those entering adult 
sexuality correlate with use of contraception and having a relationship with the partner at FSI? (4) Among university students in Poland, is there any association between early FSI on the one hand, and teenage lifestyle and certain parental characteristics on the other?

The remainder of the article is structured as follows. First, we present the broader context of religiosity and entry into adult sexuality in Poland, and look at how these processes have been changing. In the following section, we describe the data and the analytic approach we use, including the operationalisation and the definitions of the dependent and independent variables. In the next section, we present the empirical results of our survival analyses, primarily using a descriptive approach that is followed by multivariate analyses. Finally, we provide some concluding remarks and discuss the potential directions of future changes in these trends and of further research.

\section{Polish context of religiosity and entry into adult sexuality}

Poland is a Central European country where traditions have been shaped by the Latin and Slavonic cultures, and the status of the Roman Catholic Church is high. Unlike in the other former Soviet Bloc countries, in Poland, the rates of those attending church regularly and declaring themselves as believers remained high throughout the communist period (e.g., Borowik, 2002; Gautiert, 1997; Müller \& Neundord, 2012; Molteni, 2017). Although various forced secularisation policies were implemented by the communist regime, the clergy were persecuted, and engaging in religious practices and teaching religion became difficult, the percentage of the Polish population who claimed to be members of the Catholic Church did not fall during the communist era. Resistance to the communist regime and links between the Church and the Solidarity movement may have added meaning to declarations of membership in the religious community, and strengthened the position of the Church in Polish society (McQuillan, 2004). The substantial systemic changes that took place in the 1990s in the wake of the country's political and socioeconomic transformation did not change the relationship between Poles and the Church. Indeed, among the post-communist countries of Central Europe, Poland has the highest percentage of the population belonging to the Roman Catholic denomination (Need \& Evans, 2001; Pickel, 2009; Molteni, 2017). The percentage of adult Poles who claims to be believers exceeds $90 \%$ (92-97\%), while the percentage of those who say they are (partly or completely) non-believing remains rather low (3-8\%) (CBOS, 2018). Most young Poles are brought up in Catholic families and receive religious instruction at school (95\% of elementary and 92\% secondary school students received religious instruction in the 2009/ 2010 school year) (CSO, 2014), where they learn exemplary patterns of religious behaviour and the principles of Christian moral ethics.

However, over the past few years, rates of religious instruction attendance have clearly been dwindling. In the 2018/2019 school year, the average religious instruction attendance rate at secondary schools was $81 \%$, with schools in some larger cities reporting a rate of around 50\% (ISCC, 2020). Research on changes in religiosity has confirmed that participation in religious practices in Poland has been slowly decreasing (Adamczuk, Firlit, \& Zdaniewicz, 2013; Molteni, 2017). Between 1991 and 2012, the percentage of Poles who reported regularly engaging in religious practices decreased from 52 to $48 \%$, with the share being particularly low among young people ( $28 \%$ among 
those aged 18-24 years) (Adamczuk et al., 2013). Between 2005 and 2014, the proportion of Poles who said that they follow Church directives fell from 65 to below 40\%, and the share of Poles who described themselves as believers who are religious in their own way increased from 32 to $52 \%$ (CBOS, 2015).

These ongoing changes in the religious practices of young Poles may reflect the decreasing influence of Church teachings and religious belief on life choices, particularly with regard to new family behaviours, such as cohabitation, extramarital births, and less restrictive attitudes towards sexuality. Although marriage remains the most common first relationship form in Poland, cohabitation has been growing in popularity since the early 1990s, with cohabitations estimated to account for nearly a third of the first relationships formed in the years 2004-2006 (Matysiak, 2009).

Data from the Fertility and Family Survey (1991) revealed that the sexual behaviour of young Poles of the previous generation had changed only slightly. Among both males and females of the 1942-1971 birth cohorts, the median age at first sexual intercourse (FSI) remained at the same level of above 20.5 years, and the proportion of teenagers who had experienced their first intercourse before age 18 was below 20\% (Holzer \& Kowalska, 1997). Research undertaken since 1990 has shown that in consecutive generations of Poles, the age at sexual initiation has been decreasing (Wróblewska, 2001; Frątczak \& Sikorska, 2009; Pastwa-Wojciechowska \& Izdebski, 2014), but at a much slower pace than in other former socialist societies. For example, the WHO's crossnational surveys, Health behaviour in school-aged children (HBSC), showed that in 1993-2010 the proportion of 15-year-olds who had experienced their FSI was lower in Poland than in most other European countries (Currie et al., 2012).

\section{Materials and methods}

Data were obtained from two comparative surveys conducted in 2001 and 2013 by the Institute of Statistics and Demography, SGH Warsaw School of Economics, called Sexual behaviours and attitudes among university students. The first study (2001) was part of an international study coordinated by a team of researchers from the University of Messina and the Max Planck Institute for Demographic Research in Rostock (Billari et al., 2007). The participants in both studies were students at large business and economics universities in Poland who were 19-23 years old at the time of the survey. The surveys were administered during randomly selected lectures offered in different years of study, and the standard questionnaire was self-completed by the respondents. The surveys attracted considerable interest among the students, and there were very few refusals to participate (resulting in a very low non-response rate). For our analysis, we excluded respondents who gave no information about their sexual initiation (1.3\% in 2001 and $3.9 \%$ in 2013) or their age at initiation (5.8\% in 2001 and $11.4 \%$ in 2013). We also excluded a small number of respondents who reported having their first heterosexual intercourse before age 13 (three respondents in 2001 and two in 2013). The respondents who were married when the survey was administered were not excluded from the sample. ${ }^{1}$ The final sample sizes were 1558 in 2001 and 1424 in 2013.

\footnotetext{
${ }^{1}$ It was determined that the married respondents (17 respondents in 2001 and 8 in 2013) had had their first sexual intercourse before marriage on the basis of the dates of these events that they provided.
} 
The basic dependent variable was the "time of sexual initiation before age 18". The time of first sexual intercourse (FSI) for each student was based on whether the respondent reported having heterosexual intercourse, and, if so, reported when it happened for the first time. ${ }^{2}$ The exposure period for risk of early sexual initiation was from age 13 to age 18. For the respondents who reported having their FSI before the age of 18, we measured the exact number of months between when they reached age 13 and their FSI. For the respondents who said they had not initiated sexual activity before age 18, a cutoff point was assumed at age 18, and they remained in the analysis as right-censored cases. In the descriptive part of this paper, we provide the data on religion and the median age at FSI calculated for all of the respondents.

We decided to set an upper limit for the exposure period at age 18 for a number of reasons. First, as all of the respondents were above age 18 at the time of the study, we were able to conduct a retrospective analysis with a completed history. In Poland, the ages at which young people typically complete their secondary education and enrol in university, ages 1819 , are also the ages at which students typically leave the parental home to move into new accommodations. Until they reach these ages, most young people live with their parents. Thus, when young people are under age 18, their parents may be able to transfer some of their values to them and exercise a level of control over their behaviour. Research has suggested that family background characteristics, such as parental religiosity, having a close relationship with their parents, family structure (being in a two-parent household), parental monitoring, and high social status, are associated with reduced sexual behaviour and an increased likelihood of sexual abstinence among adolescents (e.g., Caltabiano et al., 2006; Huebner \& Howell, 2003; Myers, 1996; Manlove, Terry-Humen, Ikramullah, \& Moore, 2006; Miller, Benson, \& Galbraith, 2001; Zimmer-Gembeck \& Helfand, 2007; Haglund and Fehring; Landor et al. 2011). The concept of development proposed by Arnett (2000) also distinguishes between late teens (up to age 18) and emerging adulthood (between ages 18 and 25), when young people become more independent and start to explore life possibilities. Moreover, given the progression of the physiological maturity of the body and the cognitive capacity for making safe and voluntary decisions, it may be assumed that boys and girls aged 14 or younger are essentially "too young" to make the transition to sexual behaviour, while those aged 15-17 may or may not be too young depending on determinants and context, and those aged 18 or older are essentially sufficiently mature to make safe and voluntary transitions (“old enough") (Dixon-Mueller, 2008).

The primary independent variable was religiosity. Religiosity was determined on the basis of answers to three questions concerning 1-the self-declared importance of religion; 2-church attendance in the teenage period (at age 13 in 2001 and at age 15 in 2013); and 3-the age at which the respondent stopped attending Mass and religious services. ${ }^{3}$ The responses to these three questions were combined to create a synthetic "religiosity" variable with the following categories:

\footnotetext{
${ }^{2}$ The actual questionnaire item was as follows: "Have you ever had heterosexual intercourse? If so, when did it happen for the first time?"

${ }^{3}$ The questions concerning religiosity were as follows: $1-$ "How important would you say religion is for you?" (with the following responses: "not at all", "very little", "fairly", "important", or "very important"); 2-"Apart from such special occasion as weddings, funerals, and baptisms, how often did you attend services connected with your religion when you were 13 years old (15 in 2013)?" (responses: "never", "sometimes during the year", "about once a month", "two or three times a month", and "once a week or more"); and 3-"How old were you when you stopped going to Mass or to services of your religion?" (responses: age (in years), "I never went to Mass or other services every week", or "I still go to Mass, or other services almost every week").
} 
i. religion is important (1-religion is important or very important, and 2-was attending Mass or other religious services regularly at least two or three times a month at age 13/15, and 3-is still going to Mass almost every week);

ii. religion is fairly important (1-religion is fairly important, 2-was attending Mass or other religious services between once a month and several times a year at age 13/15, and/or 3-stopped attending religious services at age 19 or later);

iii. religion is of little or no importance (1-religion is not at all important or is of very little importance, and 2-never attended religious services or did so occasionally at age 13/15, and 3-never goes to Mass or stopped attending religious services in his/her teenage years). ${ }^{4}$

The category religion is important includes the respondents for whom religion had always been important, and who had been regularly participating in religious activities between age 13 (or 15) and the time of the survey. The religiosity of these respondents may be regarded as steady over time. We expected to find that religiosity had a significant association with a reduced statistical risk of early FSI (Paul, Fitzjohn, EberhartPhillips, Herbison, \& Dickson, 2000).

The construction of the religiosity variable accounted for the importance of religion and the frequency of attendance at religious services at the time of the interview (i.e., after the period of observation from age 13 to age 18 adopted in the analysis). It was assumed that an individual's responses to the questions referring to his/her situation at the time of the interview were a proxy variable of his/her religiosity and frequency of attendance at Mass at age 18. In the Polish context, it is very rare for a university student who goes to church regularly to have failed to attend church services regularly before age 18 or, more generally, during adolescence. In Poland, whether a child is admitted into the Church by baptism, and whether s/he participates in religious activities at school ages, are determined by the level of religiosity of his/her parents. It is very rare for adults to undergo catechesis and confirmation, and when this occurs, it is usually related to marriage and takes place at ages older than those of the respondents in the two surveys. The frequency of the respondents' attendance at Mass when they were age 13 (2001) or age 15 (2013) was very strongly associated with the current attendance levels of their parents. If a respondent's mother or father was attending church at least two or three times a month, there was a high likelihood that s/he was attending Mass just as regularly (this correlation was found for $95 \%$ of the respondents in the 2001 survey and for more than 90\% the respondents in the 2013 survey). Given this very high correlation between the religiousness of the respondents in their teenage years and that of their parents, we chose not to include the parents' attendance at Mass in the analysis as a control variable.

A number of the control variables used in our analysis were selected based on previous research on religion and adolescent sexual behaviour, and on the availability of variables in our surveys. There were differences in the phrasing of certain questions in the questionnaires. For example, the questions used to determine the respondents' teenage lifestyles and the degree of parental monitoring differed slightly. These differences are

${ }^{4}$ In dubious cases and when it was difficult to assign a respondent to one of these categories according to the principles presented above, the response to the third question about stopping church attendance was decisive. 
indicated below when the individual variables are described. We assumed, however, that the different measurements may be regarded as equivalent.

The group of variables pertaining to the respondents' family environment comprised the level of education of the respondent's father and mother, the relations between the parents, the relations between the respondent and his/her mother and father in his/her teenage years, the degree of parental monitoring when the respondent was 16-18 years old (2013 study), and whether the respondent was allowed to stay out until late in the evening (2001 study). Another group of control variables was associated with the respondent's teenage lifestyle, such as whether the respondent was going clubs and discos at the age 16-18, how old the respondent was when s/he got drunk for the first time (2001 study), whether the respondent was drinking alcohol at ages 16-18 (2013 study), and the respondent's school achievements at age 18. ${ }^{5}$ As has been demonstrated in other studies, lifestyle variables may be strongly associated with sexual debut and sexual activity among teenagers (e.g., Bozon \& Rault, 2012; Stranges \& Vignoli, 2019; ZimmerGembeck \& Helfand, 2007).

A gender pattern of sexual behaviour and a strong association between gender and both sexual behaviours and religion in young people are well documented in the literature (e.g., Meier, 2003; Rostosky et al., 2003; Burdette et al., 2015; Zimmer-Gembeck \& Helfand, 2007). These studies suggest that separate analyses should be carried out for males and females. In our study, the gender variable was employed in both the descriptive and the model analysis, first as a variable aiding stratification and, subsequently, as a component of the new independent variable. The descriptive analysis investigated the association between sexual behaviours and the religiosity variable (with three categories) separately for each gender. Based on the findings of the descriptive analysis, two of the three categories of the religiosity variable ("religion is fairly important" and "religion is of little or no importance") were combined.

A new variable was then developed that represents the combination of the religiosity variable (with two categories) and the gender variables. This religiosity-and-gender combination variable was comprised of four categories: (i) "religion is important-females", (ii) "religion is important-males", (iii) "religion is fairly or not important-females", and (iv) "religion is fairly or not important-males". The bivariate findings showed that while both religiosity and gender influenced the timing of sexual initiation, it was a "gross" effect. By combining these two variables, it was possible to detect genderrelated differences in the effect on the dependent variable observed within one category of religiosity.

\section{Statistical approach}

Both the descriptive and multivariate analyses were based on survival analysis techniques. We were able to use this approach owing to the retrospective nature of our data, which included calendar data, such as the birth date and the date of sexual initiation, as well as information regarding the respondent's lifestyle, religiosity, and relationship with his/her parents when $\mathrm{s} / \mathrm{he}$ was a teenager. The second reason why we chose to use survival analysis techniques was the considerable presence of censored data, that is, of individuals who had not initiated sexual activity by their 18th birthday.

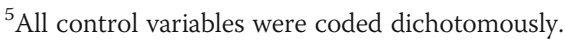


The Kaplan-Meier survival statistic was used to calculate the median age at the initiation of sexual contact. The log-rank test was used to examine homogeneity across the categories of primary covariates. The multivariate analysis was based on a proportional hazards model, which served to estimate the effect of the study variables on the early timing of sexual initiation (the exposure time was the time between age 13 and age 18). ${ }^{6}$ We first estimated crude hazard ratios (HR) with $95 \%$ confidence intervals (CI) for early initiation for the religiosity-and-gender variable (Model 1), and then the net effects of each gender-and-religiosity category by adding the variables describing the respondents' family characteristics and relationships with their parents in their teenage years (Model 2), and the variables describing the respondents' lifestyles in that period (Model 3).

Separate analyses were conducted for the 2001 and 2013 data. It was assumed that considerable changes could have taken place both in the transition to first intercourse and in the impact of the primary independent variable and other covariates on the dependent variable. ${ }^{7}$

\section{Results}

Religiosity and the timing of FSI among students

Almost half of the female students and one-third of the male students in the 2001 study stated that they regularly participated in religious activities, both as teenagers and as university students and that religion was important or very important to them. In the 2013 study, the proportion of the respondents in this category of religiosity ("religion is important") was lower, with the decrease being more pronounced among women (from 46 to $38 \%$ ) than among men (from 34 to $31 \%$ ) (Table 1). The percentage of students who reported that they were not attending religious services or had stopped going to church in their teenage years, and who declared that religion was of little or no importance to them, increased markedly for both men and women and more than doubled for male students. At the same time, the percentage of respondents indicating that religion was fairly important to them decreased.

Initiation of sexual contact below age 16 was very rare in both studies, with sexual initiation generally occurring between the ages of 16 and 18 . However, the vast majority of the respondents had not yet had their FSI at age 18 (Table 1). The respondents who reported having their FSI before their 18th birthday differed from the other respondents in terms of religiosity and gender. Among the respondents who indicated that religion was important to them, the proportion who reported having their FSI was nearly half that of the respondents in the other categories of religiosity.

The median age at first intercourse across all respondents was 20.00 years in 2001 and 19.16 years in 2013, with males generally reporting younger ages than females (19.42 vs. 20.42 in 2001 and 18.83 vs. 19.25 in 2013, respectively). However, the gender difference was statistically significant in 2001 only $(p<0.001)$.

\footnotetext{
${ }^{6}$ The proportional hazards assumption was initially assessed on the basis of the log-log plot for every category of primary covariates, and then examined by regressing the scaled Schoenfeld residuals against the log of time and testing for zero slope (Hosmer \& Lemeshow, 1999).

${ }^{7}$ An approach involving the estimation of separate models has its disadvantages, as it limits the possibility of a head-to-head comparison of the numerical values of coefficients obtained for particular years.
} 


\begin{tabular}{|c|c|c|c|c|c|}
\hline & & $\begin{array}{l}\text { Religion is } \\
\text { important }\end{array}$ & $\begin{array}{l}\text { Religion is fairly } \\
\text { important }\end{array}$ & $\begin{array}{l}\text { Religion is of little or no } \\
\text { importance }\end{array}$ & Total $(n)$ \\
\hline \multicolumn{6}{|c|}{$\%$ of respondents } \\
\hline \multirow[t]{2}{*}{ Men } & 2001 & 33.5 & 37.1 & 29.4 & $\begin{array}{l}100 \\
(620)\end{array}$ \\
\hline & 2013 & 31.1 & 30.0 & 38.9 & $\begin{array}{l}100 \\
(453)\end{array}$ \\
\hline \multirow[t]{2}{*}{ Women } & 2001 & 45.8 & 41.5 & 12.7 & $\begin{array}{l}100 \\
(938)\end{array}$ \\
\hline & 2013 & 37.8 & 36.8 & 25.4 & $\begin{array}{l}100 \\
(971)\end{array}$ \\
\hline \multicolumn{6}{|c|}{$\%$ of respondents having had FSI before the 18th birthday } \\
\hline \multirow[t]{3}{*}{ Men } & 2001 & 16.5 & 42.9 & 41.7 & 33.3 \\
\hline & 2013 & 21.5 & 43.6 & 47.5 & 38.0 \\
\hline & 2001 & 8.8 & 31.1 & 34.5 & 21.3 \\
\hline Women & 2013 & 18.2 & 37.5 & 43.9 & 31.7 \\
\hline \multicolumn{6}{|c|}{ Median age at first sexual intercourse $(F S I)^{a}$} \\
\hline \multirow[t]{3}{*}{ Men } & 2001 & $22.00^{* * *}$ & 18.83 & 18.41 & 19.42 \\
\hline & 2013 & $20.17^{* * *}$ & 18.25 & 18.17 & 18.83 \\
\hline & 2001 & $22.17^{* * *}$ & 19.33 & 18.92 & 20.42 \\
\hline Women & 2013 & $21.25^{* * *}$ & 18.66 & 18.25 & 19.25 \\
\hline
\end{tabular}

***p $<0.001$

${ }^{a}$ The median age at first sexual intercourse was calculated for all the respondents using a survival technique (Kaplan-Meier)

Both studies found significant religion-related differences in the median age at FSI. However, religiosity was associated with a significant difference in the age at FSI only among the respondents for whom religion was important and whose religiosity was stable over time. The male and female students for whom religion was important had the highest median age at FSI. In 2001, the median age for this group was nearly 22 or more than 2 years higher than the median ages for the other groups. The lowest median age at FSI of 18.41 years was reported by males for whom religion was not important. In 2013, the median age at FSI was lower for respondents with all levels of religiosity, with the decrease being particularly visible among those for whom religion was important.

\section{Relationship with the partner and use of contraception at FSI before age 18}

The respondents who considered religion important were less likely to engage in sexual intercourse with a random partner than the respondents for whom religion was fairly important or not important. The female respondents were more likely than the male respondents and the respondents in the 2001 survey were more likely than the respondents in the 2013 survey to describe their relationship with their partner at FSI as steady (Table 2). Notably, very high percentages of the respondents, and especially of the female respondents, described their relationship with their partner as steady. The highest proportion (46\%) of those who were not in a steady relationship at FSI was among the male respondents in 2013. A considerable increase in the proportion of the respondents who were not in a steady relationship with their partner at FSI was also noted among males. 
Table 2 Relationship with the partner and the use of contraception at first intercourse before age 18 (\% of respondents who had their FSI before their 18th birthday)

\begin{tabular}{|c|c|c|c|c|c|c|c|c|}
\hline & \multicolumn{4}{|l|}{2001} & \multicolumn{4}{|l|}{2013} \\
\hline & $\begin{array}{l}\text { Religion } \\
\text { is } \\
\text { important }\end{array}$ & $\begin{array}{l}\text { Religion is } \\
\text { fairly } \\
\text { important }\end{array}$ & $\begin{array}{l}\text { Religion is of } \\
\text { little or no } \\
\text { importance }\end{array}$ & Total & $\begin{array}{l}\text { Religion } \\
\text { is } \\
\text { important }\end{array}$ & $\begin{array}{l}\text { Religion is } \\
\text { fairly } \\
\text { important }\end{array}$ & $\begin{array}{l}\text { Religion is of } \\
\text { little or no } \\
\text { importance }\end{array}$ & Total \\
\hline \multicolumn{9}{|c|}{ Contraception at FSI } \\
\hline None & 17.5 & 10.6 & 6.6 & 10.8 & 8.0 & 7.1 & 6.9 & 7.2 \\
\hline Condom & 73.5 & 77.5 & 84.6 & 78.2 & 79.5 & 78.1 & 83.1 & 80.3 \\
\hline Pill & 5.9 & 6.7 & 4.7 & 6.1 & 5.7 & 5.3 & 4.4 & 5.0 \\
\hline $\begin{array}{l}\text { Another } \\
\text { method }\end{array}$ & 2.9 & 4.2 & 3.7 & 3.9 & 5.7 & 8.9 & 5.0 & 6.7 \\
\hline Not sure & 0.2 & 1.0 & 0.4 & 0.8 & 1.1 & 0.6 & 0.6 & 0.7 \\
\hline \multicolumn{9}{|c|}{ Steady relationship at FSI } \\
\hline Males & 87.5 & 88.6 & 85.3 & 87.2 & 61.5 & 49.0 & 55.2 & 54.2 \\
\hline Females & 97.2 & 98.3 & 92.3 & 96.9 & 88.7 & 81.8 & 79.6 & 82.6 \\
\hline \multicolumn{9}{|c|}{ Not in a steady relationship at $\mathrm{FSI}{ }^{\mathrm{a}}$} \\
\hline Males & 12.5 & 11.4 & 14.7 & 12.8 & 38.5 & 51.0 & 44.8 & 45.8 \\
\hline Females & 2.8 & 1.7 & 7.7 & 3.1 & 11.3 & 18.2 & 20.4 & 17.4 \\
\hline
\end{tabular}

Religiosity did not have a statistically significant differentiating effect on the use of contraception among those students who had their FSI before age 18. Certain non-significant differences in the structure of contraceptive methods and religiosity could be seen only in the 2001 data of the respondents who did not use any method of contraception (they were more likely to be religious) and of those who used a condom (they were less likely to be religious). In both studies, condoms were the most popular form of contraception among those respondents who reported having their FSI before age 18 (78\% of respondents in 2001 and 80\% in 2013).

\section{FSI and the religiosity and gender variable}

The probability of not having initiated sexual activity before age 18 by the combined religiosity and gender variable (with two categories of religiosity) is shown in survival curves (Fig. 1). The curves reveal significant differences in the age at FSI among the respondents with regard to religiosity and gender. In 2001, the differences between the designated religiosity and gender categories spanned almost 2 years for both female and male students. The proportion of the respondents who had their FSI before age 18 among those for whom religion was important was similar to the proportion of the respondents who had their FSI before age 16 in the group of low-religiosity students. A decrease in the age at FSI in the period between the two studies, which was more marked among females than males, is reflected in reduced differences between the plots of the survival curves by gender in 2013. In 2001, the time to event differed significantly for each pair of the combined variables (religiosity and gender) $(p<0.001)$. However, the 2013 study indicated that as a result of ongoing changes, there were no significant differences in the timing of FSI between males and females in the same category of religiosity. Thus, over time, the timing of FSI became increasingly similar among men and women in both the religious and non-religious categories. 


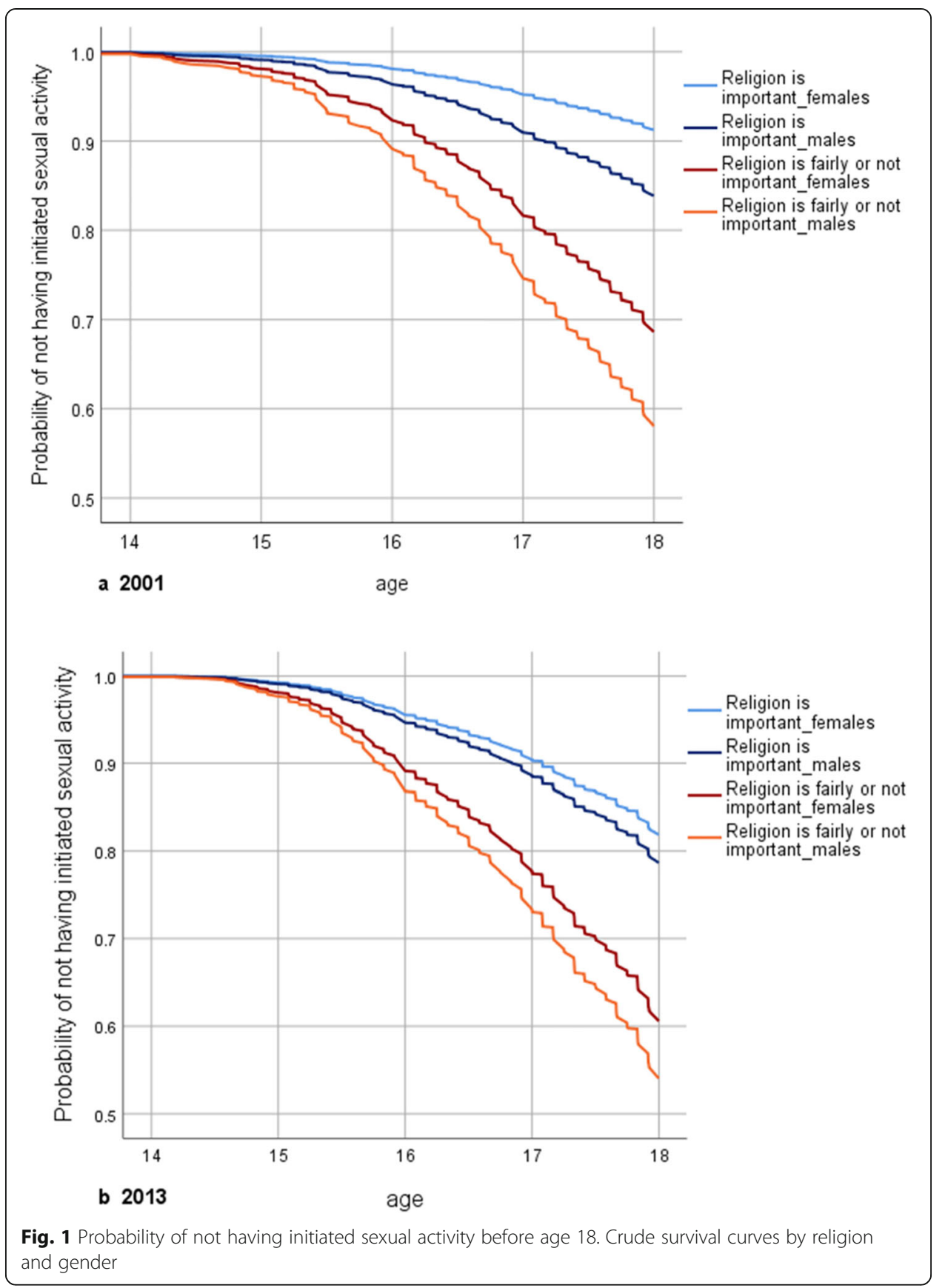

\section{Multivariable analysis}

The results of the estimation of relative religiosity and gender differences in the transition to first intercourse before age 18 obtained with a Cox regression model are presented in Table 3. The rate of first sex before age 18 was much higher among those students (males and females) for whom religion was not important or was fairly important than it was among female students for whom religion was important (reference category). Particularly high values of the hazard ratio were observed in the 2001 study, in which the estimated risks of early sexual initiation among both male and female nonreligious students were several times higher than they were among religious female 
Table 3 Hazard ratios showing the effects of religiosity and gender on experiencing first intercourse before age 18, uncontrolled (Model 1) and controlled for family characteristics (Model 2), and respondents' teenage lifestyles (Model 3)

\begin{tabular}{|c|c|c|c|c|c|c|}
\hline & \multicolumn{3}{|l|}{2001} & \multicolumn{3}{|l|}{2013} \\
\hline & $\begin{array}{l}\text { Model } \\
1\end{array}$ & $\begin{array}{l}\text { Model } \\
2\end{array}$ & $\begin{array}{l}\text { Model } \\
3\end{array}$ & $\begin{array}{l}\text { Model } \\
1\end{array}$ & $\begin{array}{l}\text { Model } \\
2\end{array}$ & $\begin{array}{l}\text { Model } \\
3\end{array}$ \\
\hline \multicolumn{7}{|l|}{ Level of religiosity } \\
\hline \multicolumn{7}{|l|}{ Religion is important—females $(=1.00)$} \\
\hline Religion is important-males & $1.824^{* *}$ & $1.790^{* *}$ & 1.245 & 1.271 & 1.266 & 1.105 \\
\hline Religion is of fairly or not important—females & $3.965^{* * *}$ & $3.779 * * *$ & $2.725^{* * *}$ & $2.543^{* * *}$ & $2.451^{* * *}$ & $2.243^{* * *}$ \\
\hline Religion is of fairly or not important-males & $5.380^{* * *}$ & $5.190^{* * *}$ & $3.000^{* * *}$ & $3.161^{* * *}$ & $2.999 * * *$ & $2.673^{* * *}$ \\
\hline \multicolumn{7}{|l|}{ Family characteristics } \\
\hline \multicolumn{7}{|l|}{ Father education level } \\
\hline \multicolumn{7}{|l|}{$($ High $=1.00)$} \\
\hline Low & & 0.917 & 1.049 & & 1.090 & 0.992 \\
\hline \multicolumn{7}{|l|}{ Mother education level } \\
\hline \multicolumn{7}{|l|}{$(\mathrm{High}=1.00)^{\mathrm{a}}$} \\
\hline Low & & 0.933 & 0.911 & & 1.029 & 1.137 \\
\hline \multicolumn{7}{|l|}{ Relationship between parents } \\
\hline \multicolumn{7}{|l|}{ (They live together $=1.00$ ) } \\
\hline They do not live together & & $1.556^{* *}$ & $1.506^{* *}$ & & $1.485^{* *}$ & $1.505^{* *}$ \\
\hline \multicolumn{7}{|l|}{ Relationship with father in teenage years } \\
\hline \multicolumn{7}{|l|}{$($ Close $=1.00)$} \\
\hline So-so or poor & & 1.006 & 1.001 & & 0.816 & 0.835 \\
\hline \multicolumn{7}{|l|}{ Relationship with mother in teenage years } \\
\hline \multicolumn{7}{|l|}{$($ Close $=1.00)$} \\
\hline So-so or poor & & 1.108 & 1.030 & & $1.380^{* *}$ & $1.491^{* *}$ \\
\hline \multicolumn{7}{|l|}{ Degree of parental supervision } \\
\hline \multicolumn{7}{|l|}{$(\text { Little or no control }=1.00)^{b}$} \\
\hline High control & & 1.036 & 1.106 & & 0.887 & 0.996 \\
\hline \multicolumn{7}{|l|}{ Teenage lifestyle } \\
\hline \multicolumn{7}{|c|}{$\begin{array}{l}\text { Age at getting drunk for the first time/alcohol exposure at age 16- } \\
18^{c}\end{array}$} \\
\hline Before age18/once a month or more often & & & $2.946^{* * *}$ & & & $1.550^{* * *}$ \\
\hline \multicolumn{7}{|l|}{ Going to clubs and discos } \\
\hline \multicolumn{7}{|l|}{ (Sometimes or never $=1.00$ ) } \\
\hline Often or very often & & & $1.905^{* * *}$ & & & $1.546^{* * *}$ \\
\hline \multicolumn{7}{|l|}{ Satisfied with outward appearance } \\
\hline \multicolumn{7}{|l|}{$($ Not or rather not $=1.00)$} \\
\hline Yes or rather yes & & & $1.662^{* * *}$ & & & $1.964^{* * *}$ \\
\hline \multicolumn{7}{|l|}{ Scholarly achievement } \\
\hline \multicolumn{7}{|l|}{ (very good $=1.00$ ) } \\
\hline Poor or good & & & 1.086 & & & 0.920 \\
\hline$-2 \mathrm{LL}$ (change in LLR) & 4238.99 & 4230.65 & 4143.94 & 5356.76 & 5332.11 & 5246.57 \\
\hline
\end{tabular}

The hazard ratios (HR) represent the relative risk of reporting first sexual experience between age 13 and 18 among respondents in a given category compared with those in the reference category ${ }^{* *} p<0.01,{ }^{* * *} p<0.001$ ${ }^{a}$ Age at completing education 22 years or older (2001); university education (2013);

${ }^{b}$ Parents allowed the respondent to come home late in the evening often or very often (ref);

'Age at getting drunk for the first time-never or over age 18 (ref. 2001); alcohol exposure at ages 16-18-never or occasionally (ref. 2013) 
students (Model 1). Males for whom religion was important were also more likely than their female counterparts to have experienced first sex before age 18. However, these differences were less significant in 2001, and they were not significant in 2013.

The inclusion of family background characteristics and variables describing the respondents' relationships with their parents and parental monitoring in their teenage years led to only minor reductions in the effects of religiosity and gender on the risk of sexual activity before age 18 (Model 2). ${ }^{8}$ In both years, only the relationship between the parents variable was significantly associated with the students' risk of sexual initiation; the risk of early initiation rose when a respondent's parents were not living together. Additionally, the 2013 study demonstrated the importance of the respondents' relationships with their mothers in their teenage years, whereby a good relationship was associated with a lower risk of initiation.

The results also revealed a strong association between sexual initiation before age 18 and the respondents' lifestyle characteristics in their teenage years. Early or frequent exposure to alcohol, going to discos, as well as being satisfied with one's outward appearance, and a sense of physical attractiveness were strongly associated with an increased risk of sexual activity (Model 3). The effects of the group of characteristics that reflect the respondents' teenage lifestyles on the risk estimates of early sexual activity were particularly evident in the 2001 study. However, in both studies, the risk ratio for early initiation was consistently significantly higher among the students for whom religion was of little or no importance than it was among the students for whom religion was important. The adjusted hazard ratio was 3.0 for male students and 2.7 for female students in 2001 and was 2.7 for male students and 2.2 for female students in 2013.

It should be stressed that among the students for whom religion was important, the effect of gender differences was reduced to non-significance in the 2001 results, controlling for other factors. In the 2013 estimates, all the models failed to show significant differences in the transition to sexual initiation before age 18 between females and males for whom religion was important. Among the students for whom religion was of little or no importance, the gender-specific risk of reporting FSI before age 18 remained higher for males than for females, controlling for other factors.

\section{Conclusions and discussion}

The focus of this work was on the poorly documented link between religiosity and sexual behaviour among young Poles, and on how this association changed during the period of social transition the ECE countries experienced after 1990. Our results indicate that students who were born or were growing up in the first two decades of the systemic transformation in Poland were less likely than previous generations to say they consider religion and religious practices important. In particular, we found that during this period, the proportions of students who stated that religion was of little or no importance to them increased, while the proportions of students who declared that religion was important or very important to them, and that they regularly participated in religious activities, not only in their teenage years, but after commencing their university studies, remained fairly stable.

\footnotetext{
${ }^{8}$ The minor importance of this group of variables is also confirmed by the finding that the fit of the models improved only slightly (change in LLR, goodness-of-fit chi-square, $p<0.01$ in 2013 and $p<0.1$ in 2001).
} 
It appears that the decrease in the importance placed on religion represented an erosion in adherence to the teaching of the Catholic Church on sexual ethics and sexrelated behaviour. This shift was reflected in our study as an increase in the proportions of students who reported having experienced their sexual debut before their 18th birthday and in a reduction of the median age at FSI. These findings suggest that the influence of religion on the sexual choices and behaviours of young Poles has been declining. Only the students who reported that religion had been an important and stable influence over time in their lives were markedly less likely to say that they had experienced their sexual debut before age 18 and were more likely to say that they had delayed their sexual debut. The students for whom religion was fairly important and who had occasionally attended Mass in their teenage years or had stopped attending while at university had a risk of first intercourse before age 18 that was as high as that of the students for whom religion was of no or very little importance, and who never attended religious services.

The similarity of the sexual behaviour patterns of these two groups of young people (low religiosity and non-religious) may be explained by the progressive secularisation of Polish society. The weakening of the position of the Church and religious institutions, including in the socio-political order, diminished the Church's presence in the public and media space, made it more difficult for the Church to enforce compliance, and reduced the Church's ability to spread religious teaching. All of these shifts served to undermine the sense of identification with and membership in the religious community among Polish young people. As a result of these dynamics, religion was no longer influencing reproductive behaviour to the same extent as it was in the past (McQuillan, 2004). Only in cases in which the sense of membership in the Church was very strong and specific religious values and moral norms were voluntarily internalised did they continue to guide the young people's choices and behaviour.

In conclusion, the findings of our study clearly showed that the likelihood of coital debut before age 18 was strongly influenced by the degree to which young people were involved in religion, as determined by their declarations about the importance they placed on religion and their church attendance. These results are essentially in line with the findings of many earlier studies conducted in other countries, which found that church attendance and greater religious involvement (e.g., membership in churchaffiliated religious groups) influence teenagers' sexual behaviour more than mere identification with a particular religious denomination or religious tradition (Miller \& Gur, 2002; Bearman \& Bruckner, 2001; Rostosky et al., 2004; Lefkowitz et al., 2004; Burdette \& Hill, 2009; Vignoli \& Salvini, 2014; Pedersen, 2014; Stranges \& Vignoli, 2019).

In addition, our analysis considered the effects of gender on the age at first intercourse, and how this parameter changed over time. Our findings showed that gender was a significant determinant of the students' behaviour in their teenage years, with young men being more likely than young women to have had their sex debut before age 18 and with young men having experienced their FSI at younger ages than young women. However, these differences between the genders were observed in the 2001 study only. The findings of the study conducted a decade later indicated that the timing of the students' sexual activity in their teenage years differed much less by gender, chiefly as a result of the acceleration of the women's entry into sexual relationships. In the two groups distinguished by the degree of religious involvement (marked vs. small 
and very small), the gender differences followed a similar patterns and faded over time, but the fundamental differences between them were preserved. An important conclusion of our study is that in the cohort of students born after 1990, there were no significant gender differences in FSI before age 18 within the religious subgroups (controlling for other factors). The changes we observed in the younger cohort-such as a reduction in the age at FSI, especially among women, and reduced gender differences-were similar to those seen in many countries of Northern and Western Europe and in the USA in the 1970s, which constituted important components of the sexual revolution (Bajos et al., 2003; Billari et al., 2007; Clement, Schmidt, \& Kruse, 1984; Robinson \& Jedlicka, 1982; King, Balswick, \& Robinson, 1977). These results may also indicate that the double standard among Polish men and women regarding sexual initiation may no longer hold. Results showing a departure from this double standard have been reported for young Italians, whose cultural context is similar to that of young Poles (Caltabiano et al., 2006).

Regarding the control variables in both studies, we found that delaying the sexual debut in the teenage years was positively related to family ties, as indicated by whether the relationship between the respondent's parents was stable and by whether the respondent had a close affective relationship with his/her mother (in 2013). These findings are consistent with the literature indicating that the good parental communication and growing up in a two-parent household have protective effects (Lammers, Ireland, Resnick, \& Blum, 2000; Myers, 1996; Karofsky, Zeng, \& Kosorok, 2001; Miller et al., 2001; Huebner \& Howell, 2003; Stranges \& Vignoli, 2019). Our finding that the differences in the risk of early sexual initiation before age 18 between the religious subgroups diminished after adjusting for teenage lifestyles confirmed our assumption that the differences between more religious and less or non-religious individuals are linked to lifestyle differences, and that there is a rationale for including these variables in analyses to elucidate the sources of such differences.

An interesting outcome of our study is our finding that there were differences between the students with respect to religiosity and the timing of sexual debut. This observation may be a starting point for further analyses of determinants of FSI in Polish youth, separately for the two religious subgroups (religious individuals vs. other individuals), who may differ with regard to the strength of the association between specific determinants and the likelihood of starting a sexual relationship. It may be supposed that among young people who attach little or no importance to religion, there is no religious "barrier" to stop them from having sex before marriage. In the other subgroup of respondents who identified themselves as religious by declaring that religion was important to them and that they attended religious services regularly, religiosity may have been a fundamental protective factor in delaying or reducing sexual relationships in their teenage years, which was likely additionally reinforced by the religiosity of their parents and friends. As Catholic sexual ethics are based on a more general set of values reflected in a number of dimensions of life, sexual abstinence is not an isolated behaviour. Instead, it co-occurs with other behaviours, such as a tendency to delay starting to drink. Importantly, in our analyses, this group was made up of students whose religiosity was consistent over time, regardless of whether they had their sexual debut. These respondents did not display the reciprocal effects of sexual initiation and religion, i.e. they did not loosen their ties with the Church or stop attending religious services following FSI (Caltabiano et al., 2006). 
Interesting as they are, our findings should be considered with the limitations of the study in mind. Our analysis relied on the results of two surveys of students attending a number of university-level institutions. Consequently, our findings cannot be extrapolated to the entire population of young people in Poland. Both patterns of religiosity and sexual behaviour and the relationship between them may be different for students and other young people who completed their education earlier. Generally, school and university students with higher academic achievement levels tend to enter sexual relationships later than others (e.g. Kontula, 2004; Billari et al., 2007; Wróblewska, 2001). The study also has limitations that are typical of cross-sectional research that may bias comparisons of outcomes over time, especially those pertaining to the association between confounding variables, which may differ across social, cultural, and structural contexts. The study did not assess the influence of the community context on the respondents' lives in their teenage years, the effects of the religious values and practices of their parents and peers, the size of the population in the area where they were living, or regional differences in levels of religiosity in Poland. In the context of the rapid decline in religious instruction at school attendance and engagement in religious practices among Polish adolescents in recent years, it is difficult to determine to what extent the effectiveness of youth ministry or the quality of religious teaching has led to these trends, or whether new forms of mass media have become the main channel shaping the opinions and sexual behaviours of young Poles.

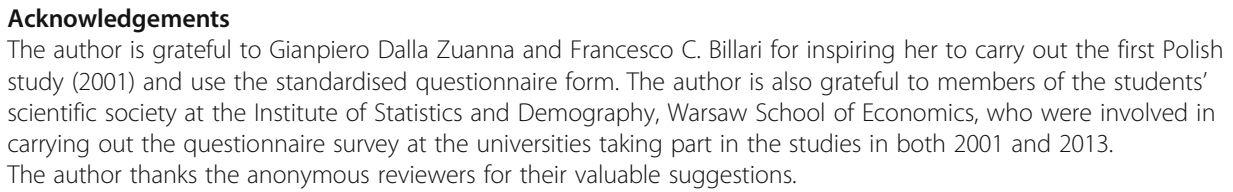
study (2001) and use the standardised questionnaire form. The author is also grateful to members of the students' scientific society at the Institute of Statistics and Demography, Warsaw School of Economics, who were involved in carrying out the questionnaire survey at the universities taking part in the studies in both 2001 and 2013.

The author thanks the anonymous reviewers for their valuable suggestions.

\section{Author's contributions}

The author declares that she fully made the concept, analysis, and drafting of the article, and finally approved the version that has been submitted.

Funding

No funds were received for this study.

\section{Availability of data and materials}

The data used in our analysis, which were derived from studies conducted by the Institute of Statistics and Demography of SGH Warsaw School of Economics, are not publicly available. However, the data are available upon reasonable request by contacting the Head of the Institute of Statistics and Demography SGH, 02-513 Warszawa, Madalinskiego 6/8 (e-mail: isd@sgh.waw.pl).

\section{Competing interests}

The author declares that she has no competing interests.

Received: 12 February 2020 Accepted: 4 June 2020

Published online: 08 July 2020

\section{References}

Adamczuk, L., Firlit, E., \& Zdaniewicz, W. (Eds.). (2013). Postawy społeczno-religijne Polaków 1991-2012. Warszawa: Institute of Statistics of the Catholic Church.

AGI. (1994). Sex and America's teenagers. New York: Alan Guttmacher Institute (AGI).

Arnett, J. J. (2000). Emerging adulthood: A theory of development from the late teens through the twenties. American Psychologist, 55(5), 469-480.

Bajos, N., Bozon, M., Beltzer, N., Laborde, C., Andro, A., Ferrand, M., Goulet, V., Laporte, A., Le Van, C., Leridon, H., Levinson, S., Razafindratsima, N., Toulemon, L., Warszawski, J., \& Wellings, K. (2010). Changes in sexual behaviours: From secular trends to public health policies. AIDS, 24(8), 1185-1191.

Bajos, N., Guillaume, A., \& Kontula, O. (2003). Reproductive health behaviour of young Europeans. (Population Studies, No. 42, Vol. 1). Strasbourg: Council of Europe Publishing

Bearman, P. S., \& Bruckner, H. (2001). Promising the future: Virginity pledges and the transition to first intercourse. American Journal of Sociology, 106(4), 859-912.

Billari, F. C., Caltabiano, M., \& Dalla Zuanna, G. (Eds.). (2007). Sexual and affective behaviour of students: An international research. Padova: Coop. Liberaria Editrice Universita di Padova. 
Borowik, I. (2002). Between Orthodoxy and Eclecticism: On the religious transformations of Russia, Belarus and Ukraine. Social Compass, 49(4), 497-508.

Borowik, I. (2006). Orthodoxy confronting the collapse of communism in post-Soviet countries. Social Compass, 53(2), 267-278.

Bozon, M., \& Rault, W. (2012). From sexual debut to first union. Where do young people in France meet their first partners? Population, 67(3), 377-410

Brenner, P. S. (2016). Cross-national trends in religious service attendance. Public Opinion Quarterly, 80(2), 563-583.

Burdette, A., Hill, T., \& Myers, K. (2015). Understanding religious variations in sexuality and sexual health. In J. DeLamater \& R. Plante (Eds.), Handbook of the sociology of sexualities (pp. 349-370). Cham, Switzerland: Springer.

Burdette, A. M., \& Hill, T. D. (2009). Religious involvement and transitions into adolescent sexual activities. Sociology of Religion, $70(1), 28-48$.

Caltabiano, M., Dalla Zuanna, G., \& Rosina, A. (2006). Interdependence between sexual debut and church attendance in Italy. Demographic Research, 14(19), 453-484.

Caltabiano, M., Dalla Zuanna, G., \& Rosina, A. (2007). Reciprocal effects of sex and religion in Italy and Poland. In F. C. Billari, M. Caltabiano, \& G. D. Zuanna (Eds.), Sexual and affective behaviour of students. An international research (pp. 295-314). Padova: Coop. Liberaria Editrice Universita di Padova.

CBOS (2015). Changes in indicators of religiosity in Poles after the death of John Paul II. (Report 31). Warszawa: Public Opinion Research Center (CBOS).

CBOS (2018). Religiousness and situation of Catholic Church. (Report 147). Warszawa: Public Opinion Research Center (CBOS).

Clement, U., Schmidt, G., \& Kruse, M. (1984). Changes in sex differences in sexual behavior: A replication of a study on West German students (1966-1981). Archives Sexual Behavior, 13(2), 99-120. https://doi.org/10.1007/BF01542145.

Coleman, L., \& Testa, A. (2008). Sexual health knowledge, attitudes and behaviours: Variations among a religiously diverse sample of young people in London, UK. Ethnicity and Health, 13, 55-72.

CSO. (2014). Kościół katolicki w Polsce, 1991-2011. Rocznik statystyczny. Warszawa: Central Statistical Office and Institute of Statistics of the Catholic Church.

Currie, C., et al. (Eds.). (2012). Social determinants of health and well-being among young people. Health Behaviour in Schoolaged Children (HBSC) study: international report from the 2009/2010 survey (Health Policy for Children and Adolescents, No. 6). Copenhagen: WHO Regional Office for Europe.

Dixon-Mueller, R. (2008). How young is "too young"? Comparative perspectives on adolescent sexual, marital, and reproductive transitions. Studies in Family Planning, 39(4), 247-262.

Eggebeen, D., \& Dew, J. (2009). The role of religion in adolescence for family formation in young adulthood. Journal of Marriage and Family, 71(1), 108-121.

Frątczak, E., \& Sikorska, I. (2009). Changing attitudes and behaviour concerning contraception and abortion in Poland. Studia Demograficzne, 2(156), 73-114.

Frejka, T., \& Westoff, C. F. (2008). Religion, religiousness and fertility in the US and in Europe. European Journal of Population, 24(1), 5-31.

Gautiert, M. L. (1997). Church attendance and religious belief in postcommunist societies. Journal for the Scientific Study of Religion, 36(2), 289-296.

Giddens, A. (2001). Sociology (4th ed.). Cambridge: Polity Press with Association with Blackwell Publishers Ltd.

Haglund, K., \& Fehring, R. (2009). The association of religiosity, sexual education, and parental factors with risky sexual behaviors among adolescents and young adults. Journal of Religion and Health, 49, 460-472.

Hoem, J. M., Kostova, D., Jasilioniene, A., \& Muresan, C. (2009). Traces of the second demographic transition in four selected countries in Central and Eastern Europe: Union formation as a demographic manifestation. European Journal of Population, 25(3), 239-255.

Holzer, J. Z., \& Kowalska, I. (1997). Fertility and family survey in countries of the ECE region. Standard country report: Poland. In Economic Studies, 10. New York and Geneva: UN.

Hosmer, D. W., \& Lemeshow, S. (1999). Applied survival analysis: Regression modeling of time to event data. New York: John Wiley.

Huebner, A. J., \& Howell, L. W. (2003). Examining the relationship between adolescent sexual risk-taking and perceptions of monitoring, communication, and parenting styles. Journal of Adolescent Health, 33, 71-78.

ISCC. (2020). Annuarium Statisticum Ecclesiae in Polonia. Warszawa: Institute of Statistics of the Catholic Church (ISCC).

Karofsky, P. S., Zeng, L., \& Kosorok, M. R. (2001). Relationship between adolescent-parental communication and initiation of first intercourse by adolescents. Journal of Adolescent Health, 28(1), 41-45.

King, K., Balswick, J., \& Robinson, I. (1977). The continuing premarital sexual revolution among college females. Journal of Marriage and Family, 39(3), 455-459. https://doi.org/10.2307/350901.

Kontula, O. (2004). Reproductive health behaviour of young Europeans, Population Studies 45. Volume 2: The role of education and information. Strasbourg, France: Council of Europe Publishing.

Kowalska, I., \& Wróblewska, W. (2008). Intergenerational changes in value system in Europe, In: Ch. Höhn, D. Avramov, I.E. Kotowska (Eds.), People, population change and policies: Lessons from the population policy acceptance study European Studies of Population, 16, Vol.1. The Haque, Netherlands: Springer Science, 157 - 175.

Lammers, C., Ireland, M., Resnick, M., \& Blum, R. (2000). Influences on adolescents' decision to postpone onset of sexual intercourse: A survival analysis of virginity among youths aged 13 to 18 years. Journal of Adolescent Health, 26(1), 42-48

Landor, A. M., \& Simons, L. G. (2019). Correlates and predictors of virginity among heterosexual African American young adults. Sexuality and Culture, 23(3), 943-961.

Lefkowitz, E. S., Gillen, M. M., Shearer, C. L., \& Boon, T. L. (2004). Religiosity, sexual behaviors, and sexual attitudes during emerging adulthood. Journal of Sex Research, 41, 150-159.

Lesthaeghe, R., \& Neidert, L. (2006). The Second Demographic Transition in the United States: Exception or textbook example? Population and Development Review, 32(4), 669-698.

Lesthaeghe, R., \& Surkyn, J. (2002). New forms of household formation in Central and Eastern Europe: Are they related to newly emerging value orientations? In UNECE, Economic Survey of Europe 2002/1 (pp. 197-216). New York and Geneva: Economic Commission for Europe, United Nations.

Lesthaeghe, R. (2010). The unfolding story of the Second Demographic Transition. Population and Development Review, 36(2), $211-251$. 
Liefbroer, A. (1999). From youth to adulthood: Understanding changing patterns of family formation from a life course perspective. In P. A. Dykstra \& L. J. G. van Wissen (Eds.), Population issues: An interdisciplinary focus (pp. 53-85). Dordrecht: Kluwer Academic/Plenum Publishers.

Manlove, J., Terry-Humen, E., Ikramullah, E. N., \& Moore, K. A. (2006). The role of parent religiosity in teens' transitions to sex and contraception. Journal of Adolescent Health, 39(4), 578-587.

Matysiak, A. (2009). Is Poland really 'immune' to the spread of cohabitation? Demographic Research, 21, 215-234.

McQuillan, K. (2004). When does religion influence fertility? Population and Development Review, 30(1), 25-56.

Meier, A. M. (2003). Adolescents' transition to first intercourse, religiosity, and attitudes about sex. Social Forces, 81, 1031-1052.

Miller, B., Benson, B., \& Galbraith, K. (2001). Family relationships and adolescent pregnancy risk: A research synthesis. Developmental Review, 21(1), 1-38.

Miller, L., \& Gur, M. (2002). Religiousness and sexual responsibility in adolescent girls. Journal of Adolescent Health, 31, 401-406.

Molteni, F. (2017). Religious change among cohorts in Eastern Europe: A longitudinal analysis of religious practice and belief in formerly communist countries. Religion and Society in Central and Eastern Europe, 10(1), 35-53.

Müller, T., \& Neundord, A. (2012). The role of the state in the repression and revival of religiosity in Central Eastern Europe. Social Forces, 91(2), 559-582.

Myers, S. M. (1996). An interactive model of religiosity inheritance: The importance of family context. American Sociological Review, 61(5), 858-866.

Need, A., \& Evans, G. (2001). Analysing patterns of religious participation in post-communist Eastern Europe. British Journal of Sociology, 52(2), 229-248.

Northmore-Ball, K., \& Evans, G. (2016). Secularization versus religious revival in Eastern Europe: Church institutional resilience, state repression and divergent paths. Social Science Research, 57, 31-48.

Pastwa-Wojciechowska, B., \& Izdebski, Z. (2014). Sexual activity of Polish adults. Ann Agric Environ Med., 21(1), 194-197.

Paul, C., Fitzjohn, J., Eberhart-Phillips, J., Herbison, P., \& Dickson, N. (2000). Sexual abstinence at age 21 in New Zealand: The importance of religion. Social Science \& Medicine, 51(1), 1-10

Pedersen, W. (2014). Forbidden fruit? A longitudinal study of christianity, sex and marriage. Journal of Sex Research, 51, 542-550.

Pickel, G. (2009). Secularization as European fate? Results from the church and religion in an enlarged Europe Project 2006. In G. Pickel \& O. Müller (Eds.), Church and Religion in Contemporany Europe (pp. 89-122). VS Verlag für Sozialwissenschaften: Weisbaden.

Pickel, G. (2011). Contextual secularization. Theoretical thoughts and empirical implications. Religion and Society in Central and Eastern Europe, 4(1), 3-20.

Pollack, D. (2008). Religious change in Europe: Theoretical considerations and empirical findings. Social Compass, 55(2), 168-186.

Pongracz, M., \& Speder, Z. (2008). Attitudes towards of partnership. In C. Höhn, D. Avramov, \& I. E. Kotowska (Eds.), People, population change and policies: Lessons from the population policy acceptance study. European Studies of Population 16 (Vol. 1, pp. 93-112). Springer Science: The Hague, Netherlands.

Regnerus, M. D. (2007). Forbidden fruit: sex and religion in the lives of American teenagers. New York: Oxford University Press.

Rizzi, E. (2004). Religiousness and sexual ethics. In G. Dalla Zuanna \& C. Crisafulli (Eds.), Sexual behaviour of Italian students (pp. 249-263). Messina, Italy: University of Messina.

Robinson, I., \& Jedlicka, D. (1982). Change in sexual attitudes and behavior of college students from 1965 to 1980: A research note. Journal of Marriage and Family, 44(1), 237-240. https://doi.org/10.2307/351277.

Rostosky, S. S., Regnerus, M. D., \& Wright, M. L. C. (2003). Coital debut: The role of religiosity and sex attitudes in the Add Health Survey. Journal of Sex Research, 40, 358-367.

Rostosky, S. S., Wilcox, B. L., Wright, M. L. C., \& Randall, B. A. (2004). The impact of religiosity on adolescent sexual behavior: A review of the evidence. Journal of Adolescent Research, 19(6), 677-697.

Sobotka, T. (2008). The diverse faces of the second demographic transition in Europe. In: T. Frejka, T. Sobotka, J.M. Hoem, L. Toulemon (Eds.), Childbearing trends and policies in Europe. Demographic Research, Special Collection 7, 19(8), 171-224.

Stranges, M., \& Vignoli, D. (2019). "Like a virgin". Correlates of virginity among Italian university students. Working Papers, No 201908, Università della Calabria, Dipartimento di Economia, Statistica e Finanza "Giovanni Anania" DESF. Retrieved from https://EconPapers.repec.org/RePEc:clb:wpaper:201908.

Štulhofer, A., Šoh, D., Jelaska, N., Baćak, V., \& Landripet, I. (2010). Religiosity and sexual risk behavior among Croatian college students, 1998-2008. Journal of Sex Research, 48, 360-371.

Surkyn, J., \& Lesthaeghe, R. (2004). Value orientations and the Second Demographic Transition (SDT) in Northern, Western, and Southern Europe: An update. Demographic Research Special Collection, 3(3), 45-86. https://doi.org/10.4054/DemRes.2004.S3.3.

Thornton, A., \& Camburn, D. (1987). The influence of the family on premarital sexual attitudes and behavior. Demography, 24(3), 323-340

Tomka, M. (1995). The changing social role of religion in eastern and central Europe: Religion's revival and its contradictions. Social Compass, 42(1), 17-26.

Vignoli, D., \& Salvini, S. (2014). Religion and union formation in Italy: Catholic precepts, social pressure, and tradition. Demographic Research, 31(35), 1079-1106.

Wellings, K., Nanchahal, K., McManus, S., Erens, B., Mercer, C. H., Johnson, A. M., Copas, A. J., Korovessis, C., Fenton, K. A., \& Field, J. (2001). Sexual behaviour in Britain: early heterosexual experience. Lancet, 358(9296), 1843-1850.

Wróblewska, W. (2001). Sexual attitudes and behaviour of Polish teenagers - intergeneration changes. Polish Population Review, 19, 112-125.

Wróblewska, W., Strzelecki, P., \& Matysiak, A. (2003). Kodeks obyczajowości seksualnej wśród młodzieży - na podstawie badania, Zachowania i postawy studentów w sferze seksualnej". In: K. Slany, A. Małek, I. Szczepaniak (Eds.), System wartości a procesy demograficzne. I Kongres Demograficzny w Polsce Krakow: NOMOS, 211-231.

Zimmer-Gembeck, M. J., \& Helfand, M. (2007). Ten years of longitudinal research on U.S. adolescent sexual behavior: Developmental correlates of sexual intercourse and the importance of age, gender, and ethnic background. Developmental Review, 28, 153-224.

\section{Publisher's Note}

Springer Nature remains neutral with regard to jurisdictional claims in published maps and institutional affiliations. 